\title{
IMPLIKATUR DALAM WACANA KAMPANYE CALON LEGISLATIF KABUPATEN TANAH BUMBU PERIODE 2019-2024: KAJIAN PRAGMATIK
}

\author{
Immplicature in Legislative Campaign Discourse Tanah Bumbu Regency 2019-2024 \\ Period: Pragmatic Study
}

\author{
Jahdiah \\ Balai Bahasa Kalimantan Selatan \\ Jalan A. Yani Km 32, Loktabat,Banjarbaru, Kalimantan Selatan \\ diah.banjar@yahoo.co.id
}

Diterima 11 Mei 2019

Direvisi 11 Juni 2019

Disetujui 25 Juni 2019

\begin{abstract}
Abstrak. Pemillihan umum 2019 memunculkan banyak masalah linguistik yang menarik untuk dikaji. Salah satunya adalah baliho calon legislatif. Penelitian in imembahas jenis-jenis tindak tutur dan implikatur yang terdapat dalam setiap tuturan dalam wacana kampanye calon legilatif di Kabupaten Tanah Bumbu. Tujuan penelitian ini mendeskripsikan jenis-jenis tindak tutur dan implikatur yang terdapat dalam baliho kampanye calon legislatif. Penelitian ini merupakan penelitian kualitatif dengan metode deskriptif. Data penelitian berupa kalimatkalimat yang terdapat dalam Baliho Kampanye calon legislatif, khusus Kabupaten Tanah Bumbu. Teori yang digunakan untuk menganalisis data dengan fokus pada tindak tutur dan implikatur. Hasil penelitian menunjukan bahwa pada baliho kampanye calon legislatif terdapat tindak tutur komisif, direktif, ekspresif, dan representatif. Implikatur yang ada pada tuturan tersebut berupa mengajak, meminta dukungan, memengaruhi, dan menyakinkan.
\end{abstract}

Kata Kunci: wacana kampanye, tindak tutur, implikatur

Abstract. Election 2019 creats lots of linguistics problems that interesting to be studied. One of them is big poster of legislative candidates. This study discusses about kind of speech act and implicature in every speech of legislative candidates big poster in Tanah Bumbu Regency. The aim of this study is to describe kind of speech act and implicature in every speech of legislative candidates big poster. It is qualitative study using descriptive method. The data are in the form of sentences in the legislative candidates big poster, especially Tanah Bumbu Regency. To analyse the data, this study usesthe theory of peech act and implicature. The result shows that on legislative candidates big poster, there are commisive speech act, directive, expressive, and representative. The implicature that exist in the speech are in the form of inviting, asking for support, persuading, and convincing.

Keywords: Campaign discourse, speech act, implicature 


\section{PENDAHULUAN}

Bahasa merupakan satu di antara karakter alami manusia. Bahasa dapat dikelompokkan menjadi dua, yaitu bahasa verbal dan bahasa nonverbal. Bahasa verbal atau bahasa sehari-hari dapat berupa tulisan, sedangkan bahasa nonverbal dapat berupa isyarat, gerakan, gambar, tindakan, aktivitas, bahkan berbagai benda (Hatinah, 2017, hlm. 1).

Baliho calon angota legislatif termasuk salah satu dari bahasa verbal dapat dikaji dengan menggunakan kajian pragmatik. Menurut (Suryatin, 2016, hlm. 28) Bahasa baliho dipandang sebagai bahasa yang efektif untuk menyebarkan visi dan misi dari kandidat calon legislatif.

Penelitian mengenai wacana kampanye politik calon legislatif sudah pernah dilakukan (Yayuk, 2011) dengan judul "Penanda Kesopanan dalam Kampanye Calon Legislatif Berbahasa Banjar Tahun 2009 di Kalimantan Selatan" Penelitian ini membahas menandai yang digunakan oleh calon legislatif. Penanda kesantunan yang digunakan dengan menggunakan kata ganti ulun dan pian, penanda kesantunan dengan ungkapan permohonan, yaitu mohon ampun, mohon doa restu dan dukungan. Suryatin (2016) juga meneliti dengan judul "Analisis Tindak Tutur pada Baliho Kampanye Calon legislatif Pemilu Tahun 2009 di Kalimatan Selatan." Hasil penelitian tersebut menyimpulkan bahwa dalam Baliho kampanye calon legislatif pemilu tahun 2009 di Kalimantan Selatan menggunakan tindak tutur lokusi, dan perlokusi. Selain itu juga tuturan pada baliho juga menggunakan tindak tutur langsung berupa kalimat perintah, sedangkan tindak tak langsung yang berupa kalimat berita.

Jahdiah (2011) meneliti bahasa calon legislatif dengan judul "Wacana Kampanye Politik Calon Legislatif
Provinsi Kalimantan Selatan Tahun 2009-2014: Suatu Tinjauan Pragmatik" Hasil penelitian ini menunjukan bahwa ada beberapa tindak tutur ilokusi yang terdapat dalam baliho calol legislatif, yaitu: 1) tindak tutur direktif memohon, meminta, mengajak 2) tindak tutur komisif berjanji, menyatakan kesanggupan, 3) tindak tutur representatif mengakui. Penelitian lain yang juga membahas kampanye politik Handono (2017) dengan judul penelitian "Implikatur Kampanye Politik dalam Kain Rentang di Ruang Publik" Hasil penelitian ini membuktikan bahwa implikatur konvensional yang timbul adalah menyakinkan, mengajak, meminta, menjanjikan dan memerintahkan. Implikatur tersebut bersumber pada penerapan prinsip kerja sama dan prinsip kesantunan. Penerapan prinsip kerja sama ,meliputi pemenuhan dan pelanggaran maksim kuantitas, kualitas, relevansi, dan cara. Sementara itu untuk penerapan prinsip kesantunan, meiputi pemenuhan maksim ketimbangrasaan.

Berbeda dengan penelitian sebelumnya penelitian yang berjudul "Implikatur dalam Wacana Kampanye Calon Legislatif Kabupaten Tanah Bumbu Periode 2019-2024: Kajian Pragmatik" hanya membahas mengenai jenis tindak tutur dan dihubungkan dengan implikatur yang dihasilkan oleh tututan tersebut.

Masalah yang dikaji dalam penelitian ini adalah jenis tindak tutur apa saja yang terdapat dalam wacana kampanye politik dan implikatur apa saja yang dihasilkan oleh tuturantuturan tersebut.

\section{KERANGKA TEORI}

Teori dalam sebuah penelitian berfungsi sebagai penuntun dalam analisis serta memberikan pemahaman lebih baik terhadap objek yang akan diteliti (Sudaryanto, 2015, hlm. 6). Teori 
juga membangun model atau peta yang mengambarkan data seperti apa adanya. Dengan teori, fenomena dapat disederhanakan. Penelitian ini menggunakan teori tindak tutur dan implikatur.

\subsection{Pengertian Pragmatik}

Untuk memahami lebih dalam tentang pragmatik tentu kita meninjau definsi pragmatik dari pakar-pakar bahasa. Menurut (Gunawan, 2007, hlm 2) pragmatik sebagai bidang kajian dalam linguistik yang memunyai kaitan dengan sematik. Keterkaitan ini disebut semantisisme, yaitu melihat pragmatik sebagai bagian dari semantik dan komplementarisme atau melihat semantik dan pragmatik sebagai dua bidang ilmu yang saling melengkapi. Putrayasa ( (2015, hlm. 14 ) mengatakan pragmatik merupakan telaah penggunaan bahasa untuk mengungkapkan maksud dalam tindak komunikasi sesuai dengan konteks dan keadaan pembicara. Dengan kata lain pragmatik menelaah bentuk bahasa dengan mempertimbangkan satuansatuan yang menyertai sebuah ujaran, kontek lingual maupun konteks ekstralingual, yaitu tujuan, situasi, partisipan, dan sebagainya. Sementara itu, (Yule, 2006, hlm 3-4) memandang pragmatik meliputi empat ruang lingkup. Pertama, pragmatik merupakan studi tentang maksud penutur. Kedua, pragmatik adalah studi tentang makna kontekstual. Ketiga, pragmatik adalah studi tentang bagaimana agar lebih banyak yang "disampaikan" dari pada yang "dituturkan". Keempat, pragmatik adalah studi tentang pengungkapan dari jarak hubungan".

\subsection{Tindak tutur}

Tindak tutur merupakan bagian dari peristiwa tutur dan peristiwa tutur merupakan bagian dari situasi tutur. Setiap peristiwa tutur terbatas pada kegiatan dan aspek-aspek kegiatan yang secara langsug diatur oleh kaidah dan norma bagi penutur. Ujaran atau tindak tutur dapat terdiri atas satu tindak tutur atau lebih dalam suatu peristiwa tutur. Dengan demikian, ujaran atau tindak tutur sangat tergantung dari konteks ketika penutur bertutur (Alwasilah, 2017, hlm. 47)

Pembagian tindak tutur berdasarkan maksud penutur ketika berbicara (ilokusi) dibagi dalam lima jenis. Pembagian ini didasarkan atas asumsi "berbicara menggunakan suatu bahasa adalah mewujudkan perilaku dalam aturan tertentu." Menurut (Putrayasa, 2015, hlm. 90-92) kelima tuturan tersebut adalah sebagai berikut.

\section{Tindak Tutur Representatif}

Tindak tutur representatif adalah tindak tutur yang mengikat penuturnya akan kebenaran atas apa yang diujarkan. Jenis tindak tutur ini disebut juga tindak tutur asertif. Adapun yang termasuk ke dalam jenis tindak tutur ini adalah tuturan menyatakan, menuntut, mengakui, melaporkan, menunjukkan, menyebutkan, memberikan kesaksian, berspekulasi, dan sebagainya.

\section{Tindak Tutur Komisif}

Tindak tutur Komisif adalah tindak tutur yang mendorong pembicarauntuk melaksanakan apa yang disebutkan di dalam tuturannya. Berjanji, bersumpah, mengancam, menyatakan kesanggupan, berkaul merupakan tuturan yang termasuk ke dalam jenis tindak komisif.

\section{Tindak Tutur Direktif}

Tindak tutur direktif sering juga disebut dengan tindak tutur impositif, adalah tindak tutur yang dimaksudkan penuturnya agar mitra tutur melakukan tindakan yang disebutkan di dalam 
tuturan itu. Adapun yang termasuk ke dalam jenis tindak tutur ini antara lain memaksa, mengajak, meminta, menyuruh, menagih, mendesak, memohon, menyarankan, memerintah, memberikan $a b a-a b a$, dan menantang.

\section{Tindak Tutur Ekspresif}

Tindak tutur ekspresif adalah tindak tutur yang dimaksudkan penuturnya agar ujarannya diartikan sebagai evaluasi tentang hal yang disebutkan di dalam tuturan itu. Tuturan-tuturan memuji, mengucap-kan terima kasih, mengkritik, mengeluh, menyalahkan, mengucapkan selamat, dan menyanjung termasuk ke dalam jenis tindak tutur ekspresif.

\section{Tindak Tutur Deklarasi}

Tindak tutur deklaratif atau deklarasi, yaitu tindak tutur yang berfungsi memantapkan sesuatu yang dinyatakan, antara lain dengan setuju dan tidak setuju, benar-benar salah, dan sebagainya.

\subsection{Implikatur}

Istilah 'implikatur' dipakai oleh Grice untuk menerangkan apa yang mungkin diartikan, disarankan atau dimaksudkan oleh penutur, yang berbeda dengan apa yang sebenarnya dikatakan oleh penutur (Brown dan Levinson , 1996, hlm. 31). Dalam suatu tindak percakapan, setiap bentuk tuturan (utterance) pada dasarnya mengimplikasikan sesuatu. Implikasi tersebut adalah proposisi yang biasanya tersembunyi di balik tuturan yang diucapkan, dan bukan merupakan bagian dari tuturan tersebut. Pada gejala demikian tuturan berbeda dengan implikasi (Wijana, 1996, hlm 37) Adanya perbedaan antara tuturan dan implikasi kadang-kadang dapat menyulitkan mitra tutur untuk memahaminya. Namun, pada umumnya antara penutur dan mitra tutur sudah saling berbagi pengalaman dan pengetahuan sehingga percakapan dapat berjalan dengan lancar.

Dengan demikian, implikatur mengisyaratkan adanya perbedaan antara tuturan dengan maksud yang ingin disampaikan. Menurut Wijana (1996, hlm. 38) dengan tidak adanya keterkaitan semantik antara suatu tuturan dengan yang diimplikasikan, maka dapat diperkirakan bahwa sebuah tuturan akan memungkinkan menimbulkan implikatur yang tidak terbatas jumlahnya.

Menurut Levinson implikatur percakapan (conversational implcature) merupakan konsep yang cukup penting dalam pragmatik karena empat hal:

1. konsep implikatur memungkinkan penjelasan fakta-fakta kebahasaan yang tidak terjangkau oleh teori linguistik.

2. konsep implikatur memberikan penjelasan tentang makna berbeda dengan yang dikatakan secara lahiriah.

3. konsep implikatur dapat menyederhanakan struktur dan isi deskripsi semantik.

4. konsep implikatur dapat menjelaskan beberapa fakta bahasa secara tepat.

Selanjutnya, Grice (1991) merumuskan adanya lima ciri implikatur percakapan. Pertama, dalam keadaan tertentu, implikatur percakapan dapat dibatalkan baik dengan cara eksplisit maupun dengan cara kontekstual. Kedua, ketidakterpisahan antara implikatur percakapan dengan cara mengatakan sesuatu. Biasanya tidak ada cara lain yang lebih tepat untuk mengatakan sesuatu itu sehingga orang menggunakan tuturan bermuatan implikatur percakapan untuk menyampaikannya.

Ketiga, implikatur percakapan mempersyaratkan makna konvensional 
dari kalimat yang digunakan, tetapi isi implikatur percakapan tidak masuk dalam makna konvensional kalimat. Keempat, kebenaran isi implikatur percakapan tidak bergantung pada apa yang dikatakan, tetapi dapat diperhitungkan dari bagaimana tindak-an mengatakan apa yang dikatakan. Kelima, implikatur percakapan tidak dapat diberi penjelasan spesifik yang pasti sifatnya.

Teori implikatur dikemukakan Grice sebagai jalan keluar untuk menjelaskan makna bahasa yang tidak dapat diselesaikan oleh teori semantik. Berkaitan dengan itu, (Levinson, 1983, hlm 45) menyatakan bahwa: (1) Teori implikatur dapat memberikan penjelasan fungsional atas fakta-fakta kenahasaan yang tidak terjangkau oleh teori linguistik (struktural). (2) Teori implikatur memberikan penjelasan eksplisit adanya perbedaan antara apa yang diucapkan secara lahiriah dengan apa yang dimaksudkan oleh suatu ujaran dan pemakai bahasa pun memahaminya. (3) Teori implikatur dapat menyederhanakan deskripsi semantik hubungan antarklausa yang berbeda konjungsinya. (4) Teori implikatur dapat menerangkan berbagai macam gejala kebahasaan yang secara lahiriah tampak tidak berkaitan atau bahkan berlawanan, tetapi ternyata berhubungan.

Grice (yang dikutip oleh (Wijana, 1996, hlm. 37) mengatakan bahwa sebuah tuturan dapat mengimplikasikan proposisi yang bukan merupakan bagian dari tuturan bersangkutan. Proposisi yang diimplikasikan itu disebut implikatur. Lebih jauh, Grice mengelompokkan implikatur menjadi dua, yaitu implikatur konvensional dan implikatur nonkonvensional (percakapan). Implikatur konvensional dapat ditangkap dengan memahami makna gramatikal kata-kata di dalam sebuah tuturan. Sebaliknya, implikatur percakapan hanya dapat ditangkap hanya jika sebuah tuturan dihubungkan dengan sebuah konteksnya.

Levinson (1983, hlm 67) melihat kegunaan konsep implikatur itu terdiri atas empat, yaitu: (1) dapat menjelaskan fungsional yang bermakna atas faktafakta kebahasaan yang tidak terjangkau oleh teori linguistik, (2) dapat memberikan suatu penjelasan yang tegas/eksplisit tentang bagaimana kemungkinan bahwa apa yang diucapkannya secara lahiriah berbeda dengan apa yang dimaksud dan bahwa pemakai bahasa itu mengerti pesan yang dimaksud, (3) dapat menyederhanakan pemerian semantik dari perbedaan hubungna antar klausa, walaupun klausa-klausa itu dihubungkan dengan kata-kata dengan struktur yang sama, (4) dapat menerangkan berbagai fakta/gejala yang secara lahiriah kelihatan tidak berkaitan dari/atau berlawanan (dalam (Nababan, 1987, hlm. 28--30).

\section{METODE PENELITIAN}

Metode merupakan upaya strategis untuk memecahkan masalah yang meliputi menyediaan data, analisis data, dan penyajian hasil analisis data (Sudaryanto, 2015, hlm 6) Penelitian ini merupakan penelitian kualitatif dengan metode deskriptif. Alasan penelitian menggunakan metode deskriptif karena penelitian ini bertujuan untuk memaparkan data apa adanya tanpa rekayasa. Data penelitian ini berupa tuturan kampanye politik calon legislatif 2019-2024 Kabupaten Tanah Bumbu yang terdapat dalam baliho. Penyedian data dilakukan dengan metode simak dengan didukung teknik 
rekam dan catatan. Metode simak ini dapat disejajarkan dengan metode pengamatan atau observasi dalam ilmu sosial dan ilmu lain. (Sudaryanto, 2015, hlm. 15).

Data yang terkumpul diklasifikasi dan dianalisis melalui pendekatan pragmatik dengan menggunakan metode padan, yaitu metode yang alat penentunya berada di luar dan tidak menjadi bagian dari bahasa yang bersangkutan (Sudaryanto, 2015, hlm. 15 ).

\section{HASIL DAN PEMBAHASAN}

Untuk keperluan analisis ejaan dan tulisan disesuaikan dengan Pedoman Umum Ejaan Bahasa Indonesia tanpa mengubah maksud dan tujuan yang ada pada baliho kampanye calon legislatif. Berikut analisis dan pembahasan baliho kampanye calon legislatif Kabupaten Tanah Bumbu berdasarkan analisis pragmatik.

\section{Data 1}

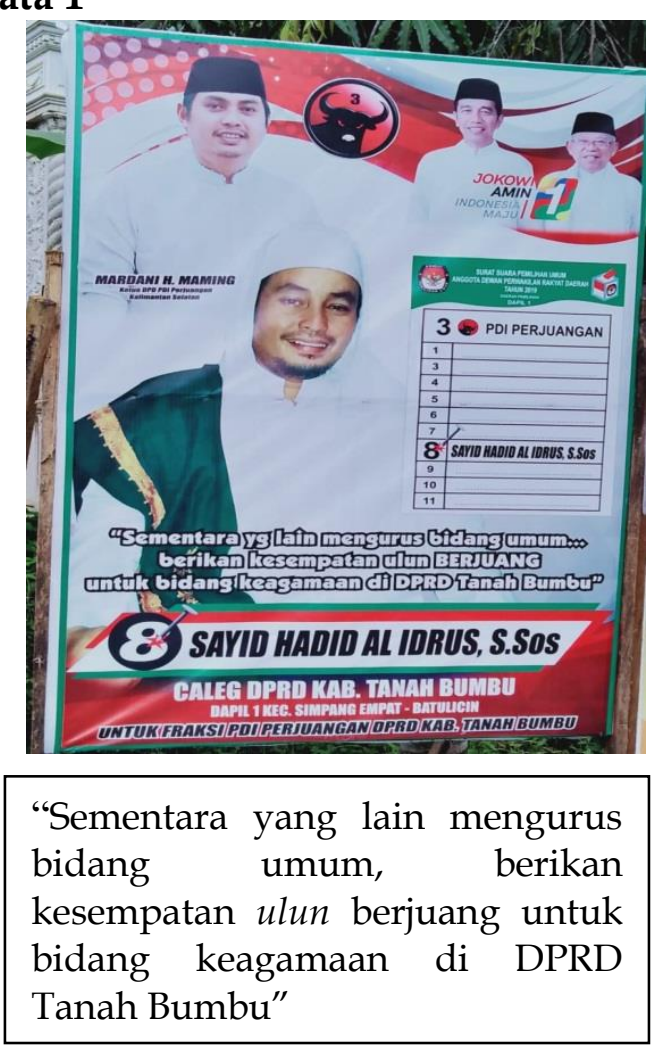

calon legislatif dari PDI Perjuangan berisi tuturan" Sementara yang lain mengurus bidang umum, berikan kesempatan ulun berjuang untuk bidang keagamaan di DPRD Tanah Bumbu." Tuturan yang terdapat pada baliho tersebut termasuk tindak tutur komisif menyatakan kesanggupan. Tindak komisif menyatakan kesanggupan adalah tindak tutur adalah tindak tutur yang mengikat penuturnya untuk melaksanakan apa yang disebutkan di dalam tuturan yang berfungsi untuk menyatakan kesanggupan. Tuturan yang disampaikan oleh caleg PDI Perjuangan melalui tuturan menyatakan kesanggupan caleg untuk berjuang untuk bidang keagamaan. Implikatur yang disampaikan oleh calon legislatif dari partai PDI Perjuangan tersebut adalah bahwa jika sudah terpilih nanti penutur berkeyakinan bahwa penutur mampu mengurus bidang keagamaan, berbeda dengan calon-calon yang lain. Penutur beranggpaan bahwa bidang keagamaan sangat penting untuk diurus karena berhubungan dengan hubungan manusia dengan Tuhan sehingga perlu penangan yang khusus.

Data 2

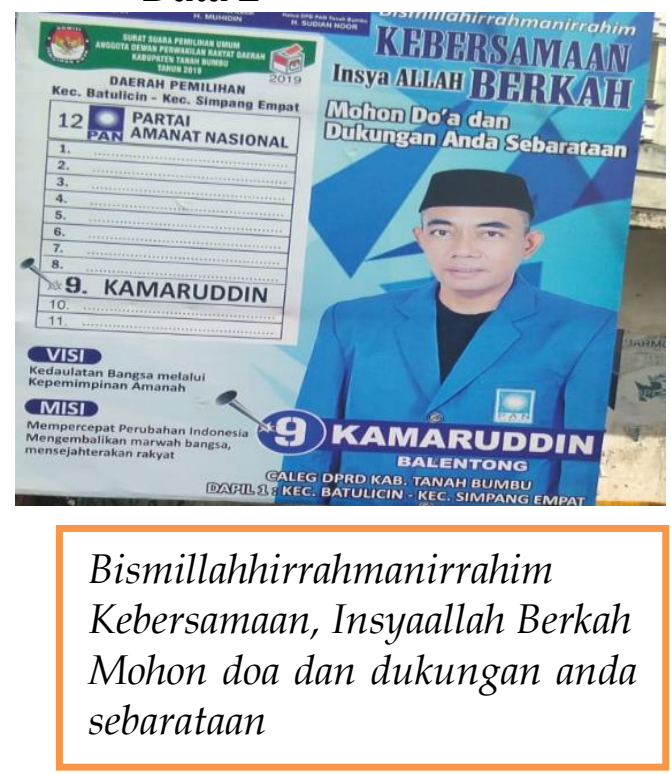


Data 2 merupakan baliho dari calon legislatif dari Partai PAN Kamaruddin dengan nomor urut 9 yang berisi tuturan Bismillah-hirrahmanirrahim kebersamaan Insyaallah Berkah Mohon doa dan dukungan anda sebarataan. Kalimatkalimat pada data (2) yang disampaikan oleh penutur bukan semata-mata untuk menginformasikan sesuatu tanpa tujuan. Tuturan yang disampaikan melalui baliho tersebut termasuk tindak tutur direktif memohon. Tindak tutur direktif memohon adalah tindak tutur yang yang juga menyatakan untuk melakukan suatu tindakan.

Penutur memohon kepada mitra tutur, calon pemilih memohan doa dan dukungan untuk memilih caleh dengan nomor urut 9 dari partai PAN Dapil 1, Kecamatan Batu Licin dan Simpang Ampat. Implikatur dalam tuturaan tersebut mengajak dam mohon kepada masyarakat untuk memilih.

\section{Data 3}

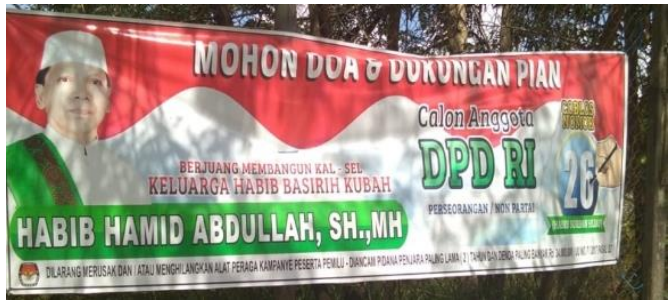

Mohon doa dan dukungan Calon Anggota DPD RI Berjuang membangun Kalsel Keluarga Habib Basirih Kubah Habib Hamid Abdullah, S.H.,M.H.

Data 3 merupakan Habib Hamid Abdullah, S.H.,M.H. sebagai anggota DPD RI berperan sebagai penutur. Tindak tutur pada data 3 termasuk tindak tutur direktif memohon, yaitu pada kalimat doa dan dukunganya. Sementara itu, kalimat Calon Anggota DPD RI Berjuang membangun Kalsel, termasuk tindak tutur komisif menyatakan kesanggupan. Tindak tutur komisif menyatakan kesanggupan adalah tindak tutur yang mengikat penuturnya untuk melaksanakan apa yang disebutkan di dalam tuturan yang berfungsi untuk menyatakan kesanggupan. Pada baliho tersebut walaupun dua tindak tutur ada, tetapi implikatur yang terdapat dalam baliho tersebut adalah meminta dukungan untuk dipilih pada pesta demokrasi yang akan di adakan pada tanggal 17 April 2019 mendatang.

\section{Data 4}

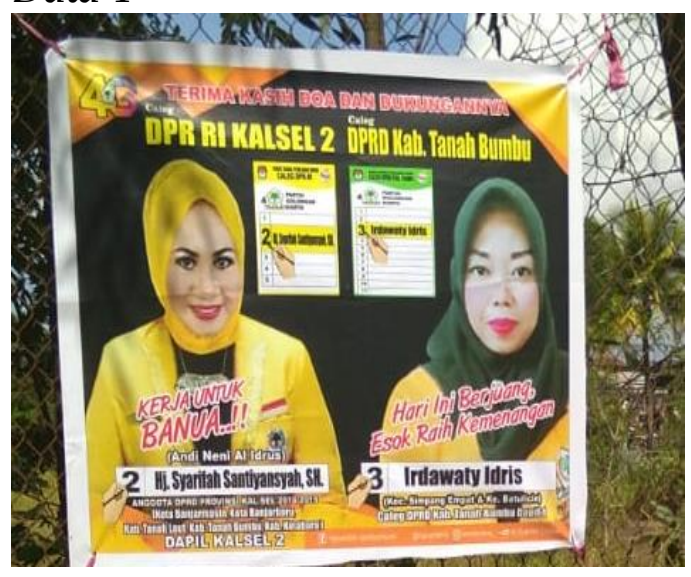

\section{Terima kasih doa dan dukungannya Kerja untuk Banua Hari ini berjuang, Esok raih kemenangan}

Tuturan Terima kasih doa dan dukungannya Kerja untuk Banua Hari ini berjuang, Esok raih kemenangan pada baliho calon anggota legislatif DPR RI dan DPRD Kabupaten Tanah Bumbu dari Partai Golongan Karya. Pada baliho tersebut berisi beberapa jenis tindak tutur. Kalimat Terima kasih doa dan dukungannya termasuk tindak tutur ekpresif berterima kasih.

Tindak tutur ekspresif mengucapkan terima kasih adalah tindak tutur yang dilakukan dengan maksud agar tuturannya diartikan sebagai evaluasi tentang hal yang 
disebutkan di dalam tuturan yang berisi ucapan terima kasih. Penutur mengucapkan terima kasih kepada mitra tutur yang akan memilih pada pesta demorasi tanggal 17 April 2019. Implikatur yang ada dalam tuturan tersebut adalah penutur optimis bahwa akan banyak yang doa dan mendukung pemilihan mendatang. Tuturan Kerja untuk BanuaHari ini berjuang, Esok raih kemenangan, termasuk tindak tutur tindak tutur komisif berjanji. Tindak tutur komisif berjanji adalah tindak tutur yang mengikat penuturnya untuk melaksanakan apa yang disebutkan di dalam tuturan berjanji. Tuturan berjanji adalah tuturan yang dilakukan untuk menyatakan suatu perjanjian. Pada tuturan tersebut calon aggota legislatif baik DPR RI maupun DPRD berjanji jika terpilih berjanji kerja untuk banua. Implikatur yang terdapat dalam baliho tersebut adalah bahwa kedua calon tersebut mampu bekerja untuk banua.

\section{Data 5}

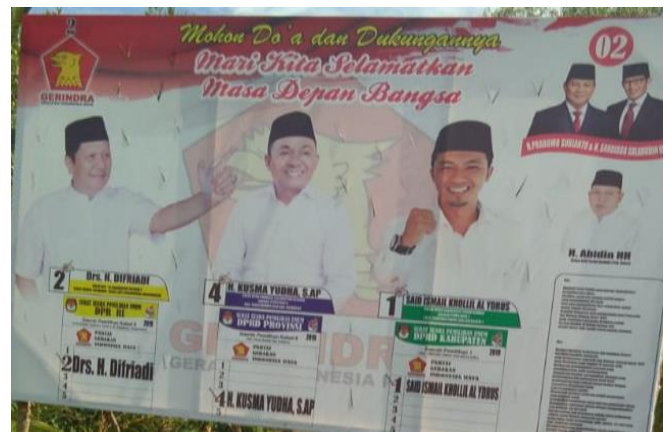

Mohon doa dan dukungannya

\section{Mari Kita Selamatkan}

Masa Depan Bangsa

Pada data tersebut terdapat tiga calon legislatif yang pada baliho tersebut, yaitu Drs. H. Difriadi, calon DPR RI , H. Kusuma Yuda S.A.P calon legislative DPRD Provinsi, dan Said Ismail Khairul DPR Kabupaten Tanah Bumbu ketiganya dari Partai Gelindra. Tuturan Mohon doa dan dukungannya yang disampai ketiga caleg tersebut termasuk tindak tutur direktif memohon. Tindak tutur direktif memohon adalah merupakan suatu tuturan yang juga menyatakan untuk melakukan suatu tindakan. Penutur memohon doa dan dukungan kepada masyarakat. Implikatur yang terdapat dalam tuturan tersebut adalah mengajak kepada mitra tutur dalam hal ini masyarakat pemilih. Tuturan Mari Kita Selamatkan, Masa Depan Bangsa termasuk tindak tutur direktif mengajak. Tuturan mengajak merupakan tuturan yang mempengaruhi mitra tutur untuk melakukan suatu tindakan. Tuturan Mari Kita Selamatkan, Masa Depan Bangsa mengajak kepada mitra tutur untuk menyelamatkan masa depan bangsa. Implikatur yang terdapat dalam tuturan tersebut adalah mengajak mitra tutur untuk memilha calon legislatif dari Partai Gelindra.

\section{Data 6}

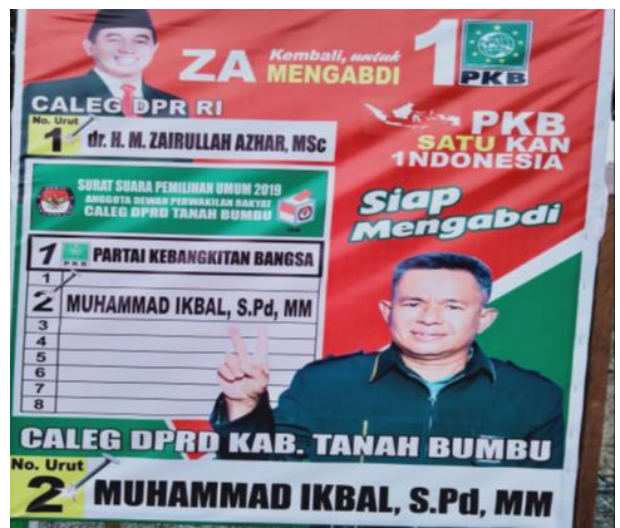

\section{ZA kembali untuk mengabdi PKP satukan Indonesia Siap mengabdi}

Data 6 merupakan baliho dari calon legislatif dari Partai Gelindra, yaitu dr. H.M. Zairullah Azhari, M.sc. calon legislative DPR RI dan Muhammas, Ikbal, S.Pd., M.M. calon legislatif DPRD Kabupaten Tanah Bumbu. Kedua calon legislatif tersebut 
menggunakan baliho sebagai sarana komunikasi dengan pendukungnya. Tuturan ZA kembali untuk mengabdi menggunakan tindak tutur representatif Tindak tutur representatif menunjukkan adalah tindak tutur yang mengikat penuturnya atas apa yang dituturkannya dengan menggunakan tuturan yang berisi menunjukkan.

ingin Pada data tersebut penutur pendukungnya bahwa Zairullah Azhar kembali untuk mengabdi sebagai calon legislatif DPR RI, implikatur yang ada mengajak mendukung untuk memilih. Sementara itu tuturan tersebut PKP satukan IndonesiaSiap mengabdi termasuk tindak tutur komisif berjanji, penutur berjanji untuk menyatukan Indonesia dan siap mengabdi. Kalimat yang diutarakan tersebut bukan semata-mata untuk menginformasikan atau berjanji saja tanpa maksud tertentu, tetapi berisi imlikatur, yaitu bahwa penutur mempengaruhi mitra tutur dalam hal ini para pendukung kedua calon legislatif tersebut.

Data 7

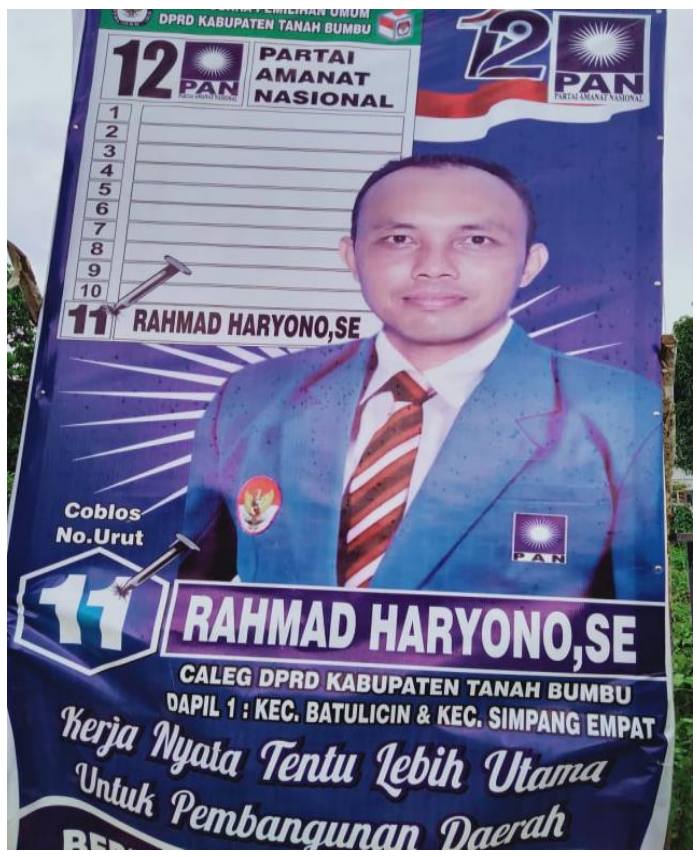

Kerja nyata tentu lebih

Utama untuk pembangunan daerah.

Pada data 7 Rahmad Haryono, S.E. sebagai calon legislatif berperan sebagai penutur. Tindak tutur pada data 7 termasuk tindak tutur refresentatif menyebutkan. Tindak tutur representatif menyebutkan adalah tindak tutur yang mengikat penuturnya akan kebenaran atas apa yang dituturkan. Implikatur yang ada dalam tuturan tersebut adalah menyakinkan mitra tutur atau pendukung untuk memilih calon legislatif dari PAN dengan nomor urut 11 dari dapil Kecamatan Batu Licin dan Simpang Empat. Berikut juga analisis implikatur dalam baliho calon anggata legislatif Kabupaten Tanah Bumbu.

\section{Data 8}

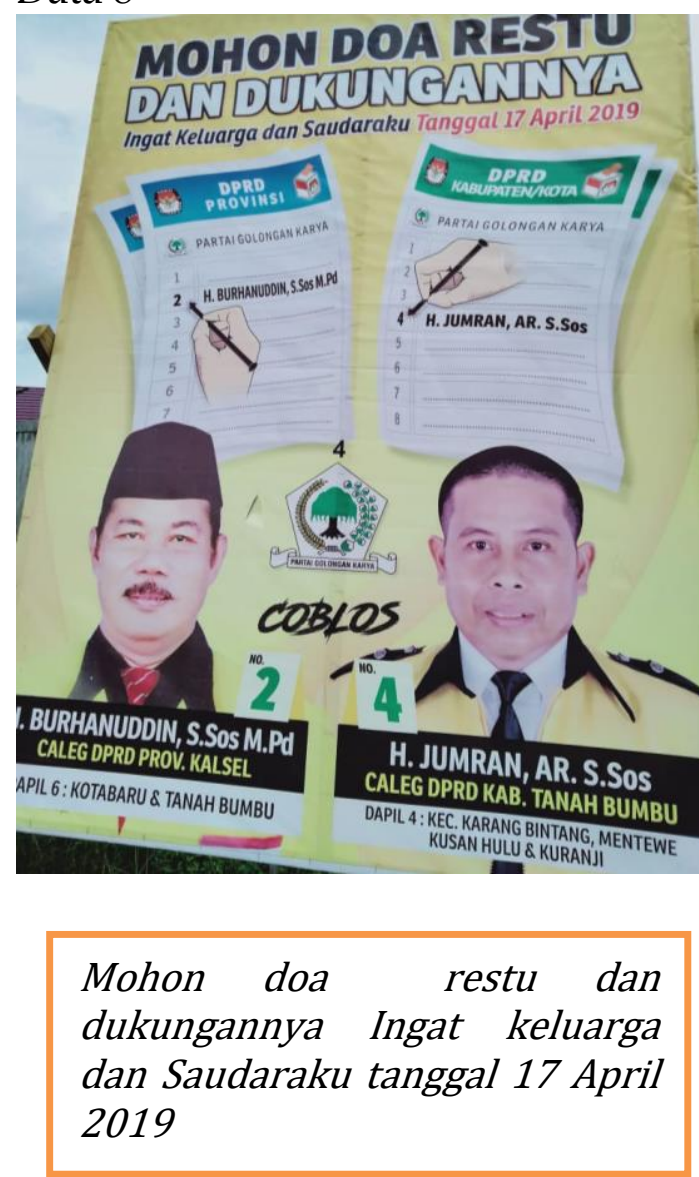


Data 8 merupakan baliho kampanye calon legislatif dari Partai Golongan Karya dengan nomor urut 2 dan 4 dari Dapil 6 Kecamatan Kotabaru dan Kecamatan Tanah Bumbu dan Dapil Kecamatan Karang Bintang, Mentewe, Kusan Hulu, dan Kuranji. Tuturan yang disampai kedua calon legislatif, yaitu Mohon doa restu dan dukungannya, termasuk tindak tutur direktif memohon, yaitu Memohon merupakan suatu tuturan yang juga menyatakan untuk melakukan suatu tindakan. Implikatur yang terdapat dalam tuturan tersebut adalah penutur meminta dukungan agar dipilih pada pemilihan pada tanggal 17 April 2019. Tuturan Ingat keluarga dan Saudaraku tanggal 17 April 2019 termasuk tindak tutur direktif meminta. Tuturan meminta menimbulkan pengaruh kepada mitra tutur untuk melakukan suatu tindakan. Tuturan yang disampai caleg dari partao Golkar tersebut meminta kepada mintra tuutr untuk mengingat bahwa pada tanggal 17April gunakan hak suara memilih. Implikatur yang terdapat dalam tuturan tersebut adalah meminta dukungan agar memilih calon legialatif dari Partai Golkar Muhammas Saini, Caleg DPRD Tanah Bumbu Dapil I.

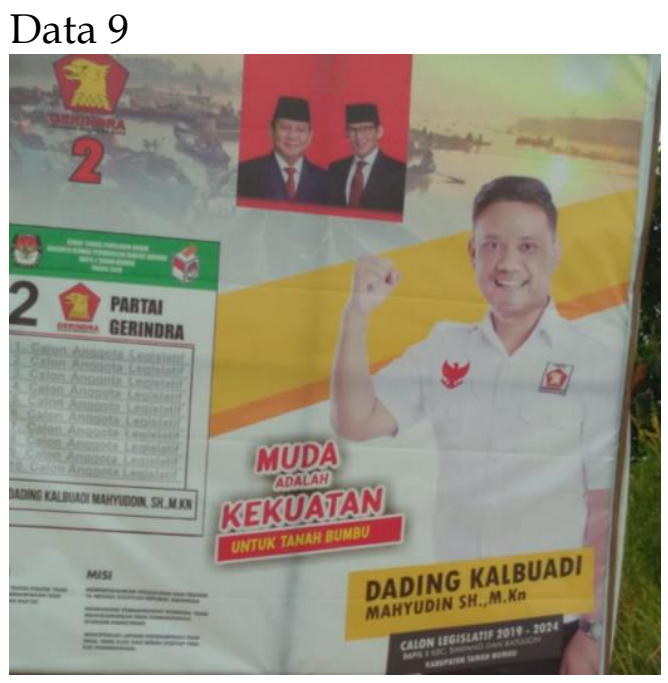

Muda adalah Kekuatan untuk Tanah Bumbu

Tuturan yang disampaikan pada data (9) yang disampaikan oleh penutur dalam hal ini Dading Kalbuadi Mahyudin, S.H., M. Kn. calon legislatif dari Partai Gerindra termasuk tidak tutur representative mengakui. Tuturan mengakui merupakan tuturan yang menyatakan keadaan yang sebenarnya, mengakui untuk diri sendiri dan orang lain akan sesuatu hal. Tuturan yang disampai tersebut mengakuan dari Calek bahwa yang muda adalah kekuatan dapat dilihat dari foto yang dipanjang pada baliho tersebut. Implikatur yang terdapat dalam tuturan tersebut adalah mengajak atau mempengarihi mitra tutur untuk memilih dengan kekuatan bahwa yang muda pasti dapat membangun Tanah Bumbu ke arah yang lebih baik.

Data 10

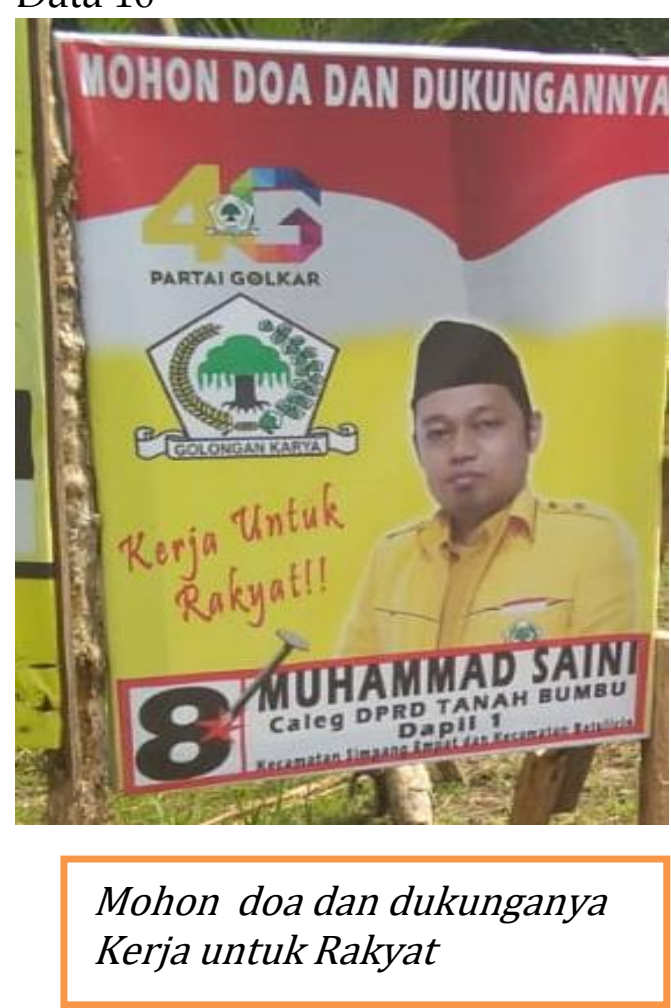


Data 10 merupakan baliho dibuat oleh calon legislatif dari Partai Golkar dengan maksud untuk mencari dukungan. Implikatur yang terdapat dalam tuturan tersebut meminta masyarakat untuk memilih sebagai anggota legislatif. Hal ini dapat diketahui dari tindak tutur Mohon doa dan dukunganya Kerja untuk Rakyat, tuturan tersebut termasuk tindak tutur direktif memohon. Memohon merupakan suatu tuturan yang juga menyatakan untuk melakukan suatu tindakan. Tuturan pada data 10 penutur memohon doa dan dukungan agar dipilih pada pemilu yang akan dilaksanakan pada tanggal 17 April 2019.

\section{Data 11}

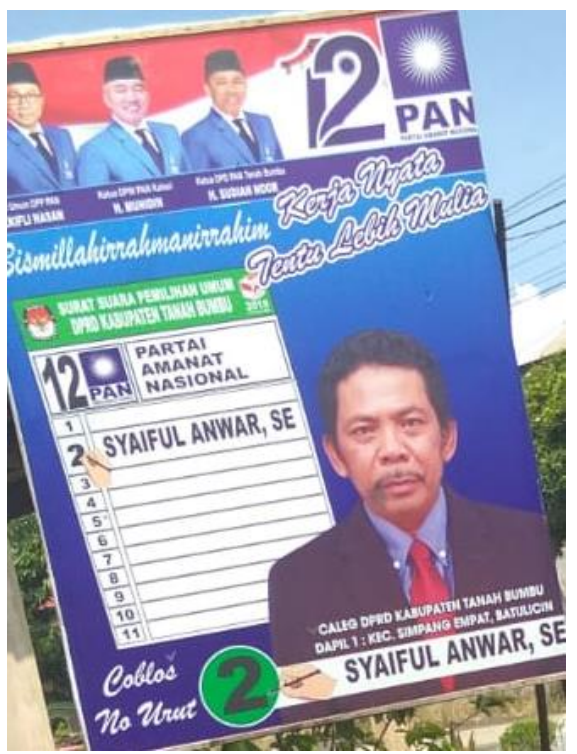

\section{Bismillahirahmannirrahim Kerja nyata, tentu lebih mulia}

Tuturan Bismillahirahmannirrahim Kerja nyata, tentu lebih mulia, yang terdapat pada baliho calon legislatif dari Partai PAN Syaiful Anwar, S.E. Tuturan tersebut termasuk tindak tutur representatif menyatakan. Tuturan menyatakan adalah tuturan yang sesuai dengan kenyataan. Calon legislatif dari PAN menyatakan bahwa kerja nyata, tentu lebih mulia. Implikatur dalam tuturan tersebut adalah menyakinkan kepada calon pemilih bahwa calon dari PAN pantas untuk dipilih.

\section{Data 12}

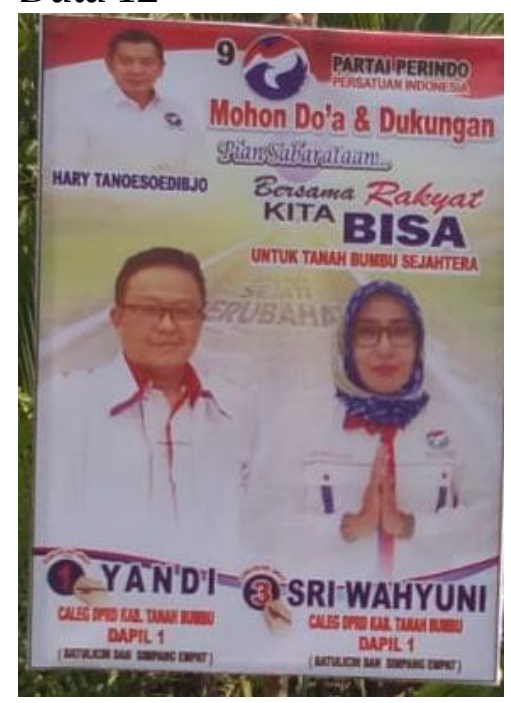

Mohon doa dan dukungan Pian baratan bersama rakyat Kita bisa untuk untuk Tanah Bumbu Sejahtera.

Data pada baliho di atas disampaikan oleh calon legislaif dari Partai Perindo. Kalimat Mohon doa dan dukungan Pian baratan bersama rakyat termasuk tindak tutur direktif memohon. Memohon merupakan suatu tuturan yang juga menyatakan untuk melakukan suatu tindakan. Implikatur yang terdapat dalam kalimat tersebut meminta masyarakat memilih Yandi dan Sri Wahyuni.

Kalimat Kita bisa untuk untuk Tanah Bumbu Sejahtera. Termasuk tindak tutur komisif menyatakan kesanggupan. Tindak tutur komisif menyatakan kesanggupan adalah tindak tutur yang mengikat penuturnya untuk melaksanakan apa yang disebutkan di dalam tuturan yang berfungsi untuk 
menyatakan kesanggupan. Tuturan yang disampaikan terseunt menyatakan kesanggupan untuk membangun Tanah Bumbu lebih sejahtera dari sebelumnya. Implikatur yang terdapat dalam tuturan tersebut adalah mengajak untuk memilih mereka berdia dari Partai Perindo.

\section{Data 13}

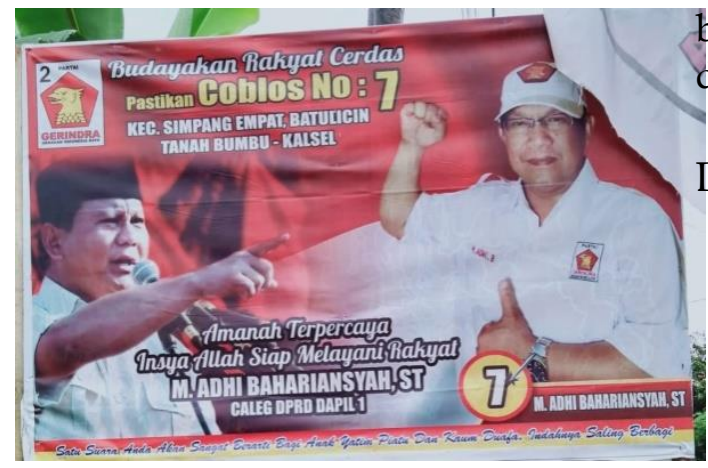

\section{Budayakan rakyat cerdas Pastikan coblos nomor 7 Amanah terpercaya.Insyaallah siap melayani rakyat.}

Data 13 banyak berisi jenis tindak tutur yang terdapat dalam wacana kampanye pemilu. Kalimat Budayakan rakyat cerdas termasuk tindak tutur direktif mengajak. Tuturan mengajak merupakan tuturan yang mempengaruhi mitra tutur untuk melakukan suatu tindakan. Pada kalimat tersebut penutur mengajak mitra tutur. Kalimat Pastikan coblos nomor 7 Amanah terpercaya. Termasuk tindak tutur representatif menunjukan. Tindak tutur representatif menyebutkan adalah tindak tutur yang mengikat penuturnya akan kebenaran atas apa yang dituturkan dengan tuturan yang berisi menyebutkan. Tuturan tersebut menunjukan bahwa nomor urut 7 amanah dan terpercaya.

Kalimat Insyaallah siap melayani rakyat termasuk tindak tutur komisif berjanji. Tindak tutur komisif berjanji adalah tindak tutur yang mengikat penuturnya untuk melaksanakan apa yang disebutkan di dalam tuturan berjanji. Tuturan berjanji adalah tuturan yang dilakukan untuk menyatakan suatu perjanjian. Insyaallah siap melayani rakyat ini merupakan janji dari calon legislatif M. Adhi Bahariansyah, S.T. calon legislatif. Implikatur yang terdapat dalam tuturan-tuturan tersebut adalah mengajak dan memengaruhi mitra tutur dengan menunjukan buktibukti dan janji-janji agar calon pemilih dapat terpengaruh.

Data 15

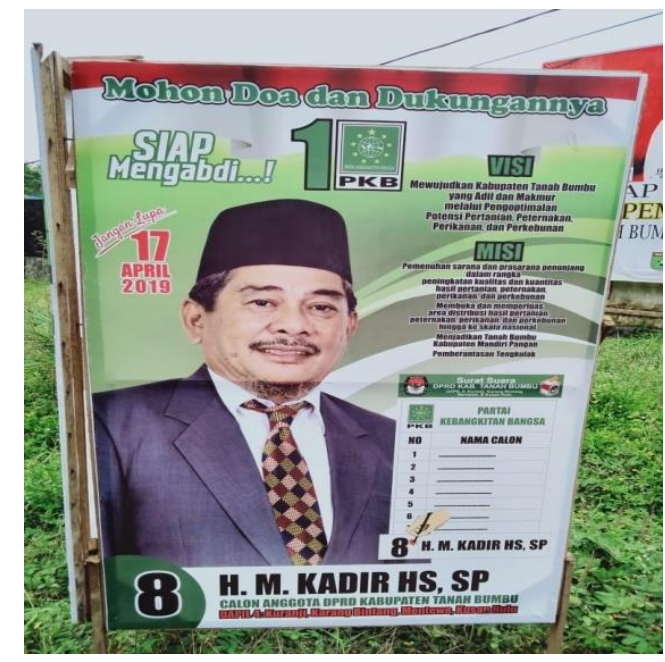

\section{Mohon doa dan dukungannya} Siap mengabdi

Data 15 Mohon doa dan dukungannya yang terdapat pada baliho calon legislatif H.M. Kadir HS, S.P. dari PKB termasuk tindak tutur direktif memohon. Memohon merupakan suatu tuturan yang juga menyatakan untuk melakukan suatu tindakan. Caleg dari PKB memohon doa dan dukungan dari masyarakat. Kalimat Siap mengabdi termasuk tindak tutur komisif menyatakan kesanggupan. Tindak tutur komisif menyatakan kesanggupan adalah tindak tutur yang mengikat penuturnya untuk melaksanakan apa yang disebutkan di dalam tuturan yang berfungsi untuk menyatakan kesanggupan. Pada kalimat tersebut 
caleg menyatakan siap mengabdi jika terpilih sebagai anggota dewan pada pemili 17 April 2019. Implikatur yang ada dalam kedua tindak tutur tersebut adalah meminta dukungan untuk dipilih.

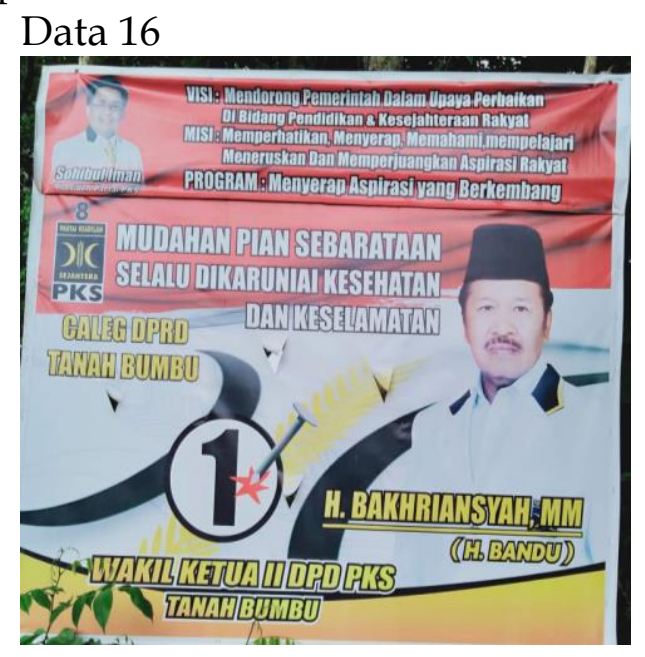

Mudahan pian sebarataan selalau dikaruniai kesehatan dan keselamatan

Caleg DPRD Tanah Bumbu $H$. Bakriansyah, M.M.

Wakil Ketua II DPD PKS Tanah Bumbu

Pada data 16 baliho di buat oleh calan legislatif dari PKS dengan maksud mencari dukungan. Kalimat Mudahan pian sebarataan selalu dikaruniai kesehatan dan keselamatan termasuk tindak tutur direktif memohon. Memohon merupakan suatu tuturan yang juga menyatakan untuk melakukan suatu tindakan. Data 16 merupakan permohon dari calon legislatif agar mitra tutur dberi karunia kesehatan. Permohon tersebut tentu ditujukan kepada Allah. Tuturan yang disampaikan tersebut buka semata-mata permohonan saja agar semua diberi kesehatan dan keselatan tetapi ada implikatur yang ingin disampaikan oleh calon legislatif dari partai PKS tersebut, yaitu meminta dukungan kepada mitra tutur agar pemilih.

Data 17

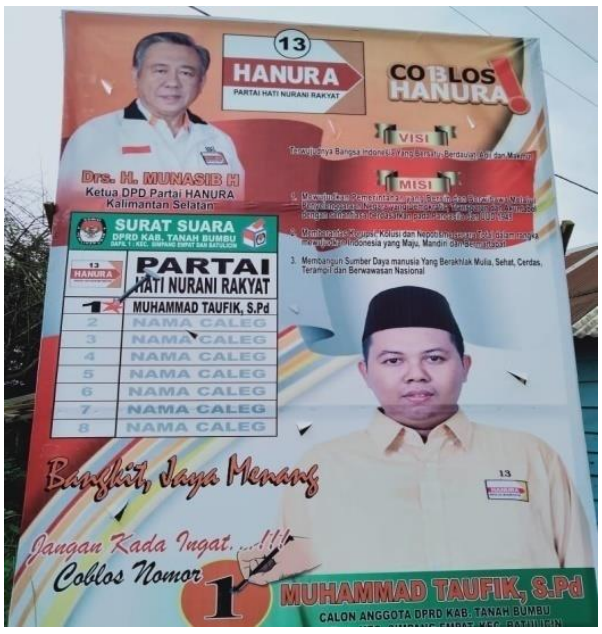

Bangkitlah, jaya menang

Jangan kada ingat coblos Muhammad Taufik, S.Pd.

Kalimat Bangkitlah, jaya menang, termasuk tindak tutur refresentatif menyebutkan. Tindak tutur representatif menyebutkan adalah tindak tutur yang mengikat penuturnya akan kebenaran. Tuturan yang disampaikan oleh caleg dari Partai Nurani Rakyat tersebut menyebutkan bahwa pasti menang. Implikatur yang terdapat dalam tuturan tersebut menyakinkan calon pemilih agar lebih yakin terhadap pilihannya. Kalimat Jangan kada ingat coblos Muhammad Taufik, S.Pd. termasuk tindak tutur direktif mengajak Tuturan mengajak merupakan tuturan yang mempengaruhi mitra tutur untuk melakukan suatu tindakan. Pada tuturan tersebut calo legislatif dari Partai Hati Nurani Rakyat meminta kepada lawan tutur untuk mencolos Muhamamd Taufik. Implikatur yang terdapat dalam tuturan tersebut adalah penutur meminta dukungan untuk memilih calon legslatif dari Partai Hati Nurani Rakyat untuk dicoblos. 
Data 18

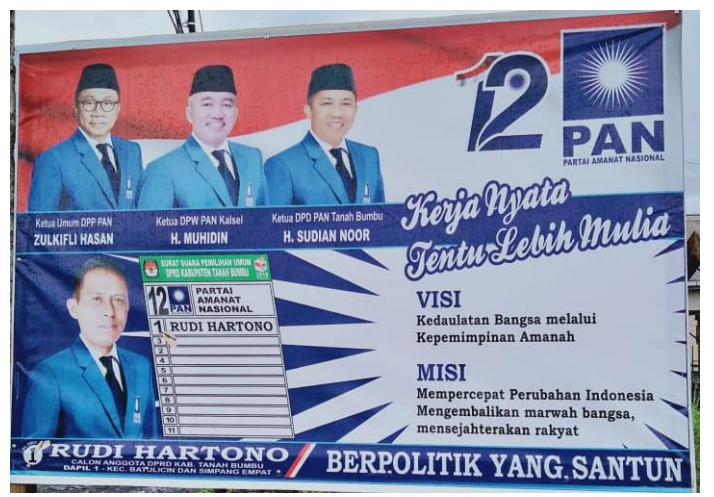

Data 19

Kerja nyata, tentu lebih mulia Rudy Hartono berpolitik yang santun.

Pada data 19 kalimat Kerja nyata, tentu lebih mulia termasuk tindak tutur representatif menunjukkan. Tindak tutur representatif menunjukkan adalah tindak tutur yang mengikat penuturnya atas apa yang dituturkannya dengan menggunakan tuturan yang berisi menunjukkan. Implikatur yang terdapat dalam tuturan tersebut adalah menyakin mitra tutur. Kalimat Rudy Hartono berpolitik yang santun termasuk tindak tutur refresentatif mengakui. Tindak tutur representatif mengakui adalah Tuturan mengakui merupakan tuturan yang menyatakan keadaan yang sebenarnya, mengakui untuk diri sendiri dan orang lain akan sesuatu hal. Pada tuturan tersebut calan legislatif dari PAN mengakui bahwa dia berpolitik secara santun. Implikatur yang ada dalam tindak tutur tersebut meminta dukungan dari masyarakat.

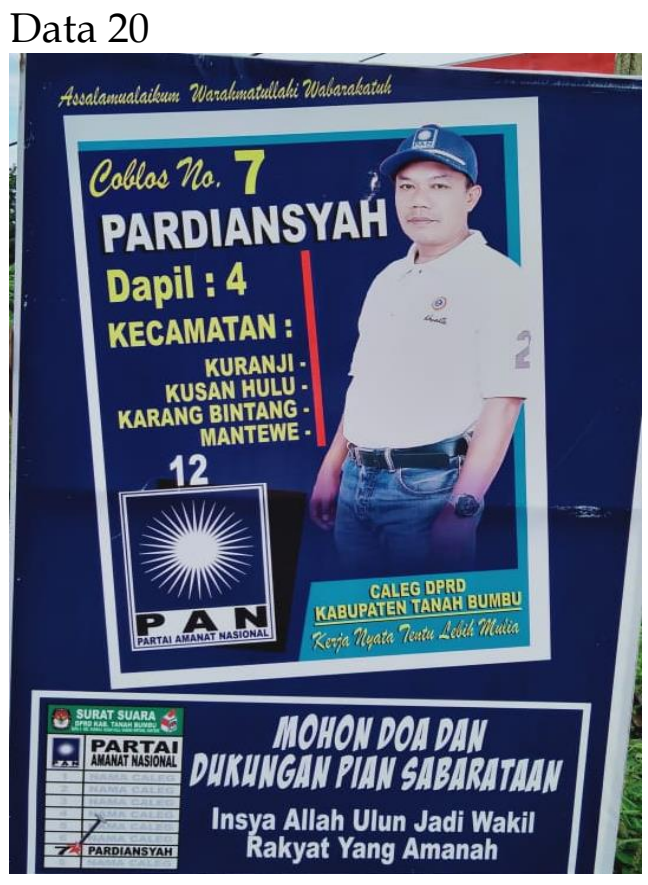

Mohon doa dan dukungan pian
barataan
Insyaallah ulun jadi wakil rakyat
yang amanah

Kalimat Mohon doa dan dukungan pian barataan termasuk tindak tutur direktif memohon. Memohon merupakan suatu tuturan yang juga menyatakan untuk melakukan suatu tindakan. Implikatur yang terdapat dalam tuturan tersebut meminta dukungan. KalimatInsyaallah ulun jadi wakil rakyat yang amanah termasuk tindak tutur komisif berjanji. Tindak tutur komisif berjanji.Tindak tutur komisif berjanji adalah tindak tutur yang mengikat penuturnya untuk melaksanakan apa yang disebutkan di dalam tuturan berjanji. Tuturan berjanji adalah tuturan yang dilakukan untuk menyatakan suatu perjanjian. Implikatur yang terdapat dalam tuturan menyakin mitra tutur atau calon memilih untuk mendukung calon legislatif dari PAN. 


\section{PENUTUP}

\section{Simpulan}

Baliho merupakan salah satu media yang digunakan oleh calon legislatif untuk menyampai pesan dan aspirasi. Berdasarkan hasil analisis dan pembahasan terdapat bahwa tindak tutur yang terdapat dalam baliho wacana kampanye berupa tindak tutur komisif berjanji, tindak tutur komisif menyatakan kesanggupan, tindak tuutr direktif mengajak, tindak tutur direktif memohon, tindak tutur ekspresif berterima kasih, tindak tutur tutur direktif memohon, tindak tutur refresentatif menunjukkan, menyebutkan, mengakui, dan menyatakan.

Berdasarkan analisis terhadap jenis-jenis tindak tutur tersebut diperoleh imlikatur berupa menyakinkan, meminta dukungan, mempengaruhi, mengajak, dan menyakinkan.

\section{DAFTAR PUSTAKA}

Alwasilah, A. C. (2017). Pokoknya Kualitatif:Dasar-Dasar Merancang dan Melakukan Penelitian Kualitatif. Bandung: Dunia Pustaka Jaya.

Brown, G. dan G. Yule. (1996). Analisis Wacana (Terjemahan). Jakarta: Gramedia.

Gunawan, A. (2007). Pragmatik:Teori dan Kajian Nusantara. Jakarta: Penerbit Universitas Atma Jaya.

Handono, S. (2017). Implikatur Kampanye Politik dalam Kain Rentang di Ruang Publik. Aksara,
29, 253--266.

Hatinah, Yulmi, dkk. (2018). Kajian Sosiopragmatik Imperatif dalam Debat Pilkada DKI Jakarta Tahun 2017.

Jahdiah. (2011). Wacana Kampanye Politik Calon Legislatif Provinsi Kalimantan Selatan Tahun 20092014:Suatu Tinjauan Pragmatik. Undas, 7(1), 7-14.

Levinson, S. (1983). Pragmatics. Cambridge: Universty Press.

Putrayasa, Ida. Bagus. (2015). Pragmatik. Yogjakarta: Grha Ilmu.

Sudaryanto. (2015). Metode dan Teknik Analisis Bahasa. Yogjakarta: Daindra Primamitra.

Suryatin, Eka (2016). Analisis Tindak Tutur Pada Baliho Kampanye Calon Legislatif Pemilu Tahun 2009 di Kalimantan Selatan. Undas, 12 (1), 27--34.

Wijana, I. D. (1996). Dasar-Dasar Pragmatik. Yogjakarta: Andi Offset.

Yule, George. (2006). Pragmatik. Yogyakarta: Pustaka Pelajar. 